\title{
Application of Response Surface Methodology to study the effect of different calcium sources in fish muscle-alginate restructured products
}

\author{
Aplicação da Metodologia Superfície de Resposta para determinar a contribuição das \\ diferentes fontes de cálcio para as propriedades do músculo reestruturado de peixe-alginate
}

Helena María MORENO ${ }^{1}$, José CARBALLOํㅜ ${ }^{1}$ Javier BORDERÍAS ${ }^{1 *}$

\begin{abstract}
Sodium alginate needs the presence of calcium ions to gelify. For this reason, the contribution of the calcium source in a fish muscle mince added by sodium alginate, makes gelification possible, resulting a restructured fish product. The three different calcium sources considered were: Calcium Chloride (CC); Calcium Caseinate (CCa); and Calcium lactate (CLa). Several physical properties were analyzed, including mechanical properties, colour and cooking loss. Response Surface Methodology (RSM) was used to determine the contribution of different calcium sources to a restructured fish muscle. The calcium source that modifies the system the most is CC. A combination of CC and sodium alginate weakened mechanical properties as reflected in the negative linear contribution of sodium alginate. Moreover, CC by itself increased lightness and cooking loss. The mechanical properties of restructured fish muscle elaborated were enhanced by using CCa and sodium alginate, as reflected in the negative linear contribution of sodium alginate. Also, CCa increased cooking loss. The role of CLa combined with sodium alginate was not so pronounced in the system discussed here.
\end{abstract}

Keywords: sodium alginate; calcium chloride; calcium caseinate; calcium lactate; restructured fish product.

\section{Resumo}

Os íons de cálcio numa polpa de peixe picado contendo alginato de sódio tornam possível a gelificação, permitindo a formação de um produto reestruturado de peixe. As três diferentes fontes de cálcio consideradas foram: cloreto de cálcio (CC), caseinato de cálcio (CCa) e lactato de cálcio (CLa). Várias propriedades físicas foram analisadas, incluindo propriedades mecânicas, cor e perda de água por cozedura. A Metodologia de Superfície de Resposta (RSM) foi utilizada para determinar a contribuição das diferentes fontes de cálcio para as propriedades do músculo reestruturado de peixe. A fonte de cálcio com o maior efeito no sistema é CC. Uma combinação de CC e alginato de sódio enfraqueceu as propriedades mecânicas, fato refletido pela contribuição negativa linear do alginato de sódio. Além disso, o CC, por si, aumentou a brancura e a perda por cozedura. As propriedades mecânicas dos músculos de peixe reestruturados foram melhoradas pela combinação do CCa com o alginato de sódio, fato refletido pela contribuição negativa linear do alginato de sódio. O CCa aumentou igualmente a perda por cozedura. A combinação do CLa com o alginato de sódio não teve um papel tão relevante neste sistema.

Palavras-chave: alginato de sódio; cloreto de cálcio; caseinato de cálcio; lactato de cálcio; produto reestruturado de peixe.

\section{Introduction}

The development of restructuring technology has made it possible to produce value-added fish products from lowcommercial-value cuts and to control product characteristics such as shape, colour, texture, fat and moisture content (RAHARJO et al., 1994; RAHARJO et al., 1995). Nowadays, consumers are interested in "fresh products". This demand has prompted attempts to produce restructured products based on chopped or minced raw fish muscle, for sale chilled and with eating characteristics similar to cuts from intact muscles. The mechanical properties of such restructured products are decisive from the standpoint of consumers' choice and acceptability (JENA; BHATTACHARTA, 2003), and therefore, it is important to consider the contribution of the ingredients or additives that are used for that purpose. Also, cold-set products are more versatile in that they can be processed in many ways, for instance; marinated products, sushi, carpaccio and ready-tocook fish fillet analogs. Although alginates are widely used in food systems as stabilizers and to modify the rheology of food solutions sols, one of their more useful properties is gelation (MEANS; SCHMIDT, 1986). Alginates are polysaccharides extracted from brown seaweed (Phaeophyce ssp, Laminariae ss, etc.) and are used mainly in the form of monovalent salt as sodium alginate. Alginate differs from other gels forming hydrocolloids, in that it forms chemically rather than thermally induced gels. Alginate gels are formed by intermolecular association of polyvalent cations (chiefly calcium and never magnesium) with dimerically associated guluronic acid block regions of the polysaccharide molecule (MORRIS, 1980). Calcium ions interact with alginate better than other polyvalent cations and are also the most commonly used source of cations in food systems. Their gelation mechanism induces changes in the cross-link of the gel and alters the mechanical properties of gel, depending on the concentration of either sodium alginate or

Recebido para publicação em 29/7/2009

Aceito para publicação em 31/10/2009 (004176)

Departamento de Ciencia y Tecnología de la Carne y Productos Cárnicos y del Pescado y Productos de la Pesca, Instituto del Frío - ICTAN, Consejo Superior de

Investigaciones Científicas - CSIC, José Antonio Nováis, 10, 28040, Madrid, Spain, E-mail: hmoreno@if.csic.es; jcarballo@if.csic.es; jborderias@if.csis.es

${ }^{*}$ A quem a correspondência deve ser enviada 
calcium salt (STOKKE et al., 2000). The alginate gel is formed at the interface, where dispersions of alginate and calcium ions come into contact with each other. Gelation depends on the diffusion of calcium ions through the gel membrane and the process can take anything from a few seconds to several hours. The strengthening of the gel depends on the gradual release of calcium ion in alginate dispersion. Alginate is different from other gels forming hydrocolloids, in that it forms thermo-stable gels without thermal treatment (MEANS; SCHMIDT, 1986). It is this gel that interacts with myofibrillar proteins. Shand, Sofos and Schmidt (1993) and Montero, Hurtado and Pérez-Mateos (2000) reported that these are mainly electrostatic interactions, between the anionic groups on the alginate and the positively charged groups on the protein. Calcium ions pull the alginate molecules together by ionic interactions, producing hydrogen bonding. The proportion of sodium alginate, calcium ion source, $\mathrm{pH}$, temperature, presence of other components and reaction time are all variables used to achieve different kinds of texture (TOLSTOGUZOV, 1986). It is also important to minimize the calcium source in order to avoid sensory problems as calcium ions can produce bitterness and astringency.

The calcium-alginate gel may interact with myofibrillar proteins. Shand, Sofos and Schmidt (1993) and Montero, Hurtado and Pérez-Mateos(2000) reported that these interactions are mainly electrostatic, between the anionic groups on the alginate and the positively charged groups on the protein. But other authors, such as Moreno, Carballo and Borderías (2008), have suggested that the alginate establishes its own gel-net, which somehow enhances the gelation of the minced muscle, although it is not clear whether it establishes bonds with proteins. Other authors similarly reported that the gel that is produced holds food particles together in a thermostable way, meaning that the restructurates retain their structural integrity despite subsequent heating (SUKLIM et al., 2004; ROOPA; BHATTACHARYA, 2008). Several researches have investigated the reaction of alginate/calcium sources with a view to modifying the texture of formed meat products (MEANS; SCHMIDT, 1986; ROOPA; BHATTACHARYA, 2008), but we have found very few results relating to the texture of minced fish products (MONTERO; HURTADO; PÉREZ-MATEOS, 2000; PÉREZ-MATEOS; MONTERO, 2000). Also, there is little information about the molecular mechanism whereby the functionality of myofibrillar proteins is improved by conjugation with alginates (URDANGARIN et al., 2004).

The objetive of this study was to evaluate the effect of three different calcium sources (calcium chloride, calcium caseinate and calcium lactate) on the physical properties of gels formed at low temperature from fish minced muscle with different concentrations of sodium alginate added by using Response Surface Methodology (RSM), with a view to make raw fish muscle restructured models or prototypes as bases for raw analog products.

\section{Materials and methods}

\subsection{Raw materials and additives}

Raw material was trimmings of hake fillets (Merluccius capensis) caught two or three months earlier and frozen stored on board $\left(-20^{\circ} \mathrm{C}\right)$.
Sodium chloride, a calcium source (calcium chloride, calcium caseinate or calcium lactate) (Panreac Quimica, S.A.; Barcelona, Spain) and sodium alginate (Degussa Texturant Systems España, S.A.; Barcelona, Spain) were used to prepare the restructured prototypes. Proportions of ingredients of different samples are shown in Table 1.

\subsection{Experimental design}

Response Surface Methodology (RSM) was used to study the simultaneous effect of the three independent variables (Sodium alginate, calcium source and $\mathrm{NaCl}$ proportions) on restructured fish product properties. The experiment was based on a central composite rotatable design. Five levels of each variable were chosen following the principles of that design (see Table 1). The variables studied were: sodium alginate $(0.05-0.5 \%)$, sodium chloride $(0-3 \%)$ and three calcium sources (calcium chloride, calcium caseinate and calcium lactate) (0.1-1.0\%). For each experiment, three in total (one for each calcium source), 20 combinations of three variables were performed following the design. Error assessment was based on six replications of the treatment in the central conditions as proposed in the design (COCHRAN; COX, 1957). For each response, a second-order polynomial aquation was fitted as follows (Equation 1):

$$
y=b_{o}+\sum_{i=1}^{k} b_{i} x_{i}+\sum_{i=1}^{k} b_{i i} x_{i}^{2}+\sum_{i<k}^{k} b_{i j} x_{i} x_{j}
$$

where $y$ is the estimated response, and bo, bi, bii, bij are the equation parameter estimates (constant: bo, parameter estimates

Table 1. Levels of variables established according to the central composite rotatable desing.

\begin{tabular}{cccc}
\hline Sample & $\mathrm{NaCl}(\%)$ & Sodium alginate $(\%)$ & Calcium source $\left.^{\star} \%\right)$ \\
\hline 1 & 1,50 & 0,28 & 0,46 \\
2 & 1,50 & 0,28 & 0,46 \\
3 & 2,39 & 0,41 & 0,14 \\
4 & 2,39 & 0,14 & 0,78 \\
5 & 2,39 & 0,14 & 0,14 \\
6 & 1,50 & 0,05 & 0,46 \\
7 & 1,50 & 0,28 & 1,00 \\
8 & 1,50 & 0,50 & 0,46 \\
9 & 0,61 & 0,41 & 0,78 \\
10 & 3,00 & 0,28 & 0,46 \\
11 & 1,50 & 0,28 & 0,46 \\
12 & 1,50 & 0,28 & 0,46 \\
13 & 0,61 & 0,41 & 0,14 \\
14 & 0,00 & 0,28 & 0,46 \\
15 & 2,39 & 0,41 & 0,78 \\
16 & 0,61 & 0,14 & 0,14 \\
17 & 0,61 & 0,14 & 0,78 \\
18 & 1,50 & 0,28 & 0,46 \\
19 & 1,50 & 0,28 & 0,46 \\
20 & 1,50 & 0,28 & 0,10 \\
\hline
\end{tabular}

* Each sample has been studied separately: Calcium Chloride -CC-, Calcium Caseinate -CCa- and Calcium Lactate -CLa. 
for linear terms: bi, for quadratic terms: bii, for interaction term: $\mathrm{b} i j), \mathrm{x} i, \mathrm{x} j$ are the levels of the factors and $k$ the numbers of factors. The significance of the equation parameters for each response variable was assessed by $F$ testing using Statgrafics plus 2.1, STSC Inc., Rockville, MD. Minimum level of significance was set for $\mathrm{p} \leq 0.05$. Three-dimensional representations were drawn to show interrelationships between two given independent variables on a given response, by imposing a constant value equal to the mid-level of the third variable.

\subsection{Sample preparation}

For each of the three experiments, the hake was ground into small muscle fragments of around 15-20 mm, by using a meat mincer (FTS 11 Model, Van Dall SRLL, Milan, Italy) and then, muscle fragments were mixed with the other components: $\mathrm{NaCl}$, Sodium alginate and the Calcium source (Calcium chloride, Caseinate and Lactate), in a refrigerated $\left(4-8{ }^{\circ} \mathrm{C}\right)$ vacuum homogenizer (Stephan UM5, Stephan u. Söhne GMBH \& Co., Hameln, Germany). The mixture was homogenized for 1 minute with each ingredient. At the end, the whole mixture was homogenized for 2 minutes more. The resulting dough was vacuum-wrapped in a petri-plate (depth $16 \mathrm{~mm}$ and diameter $96 \mathrm{~mm}$ ). The Petri-plates were kept in a cold room at $5{ }^{\circ} \mathrm{C}$ overnight.

\subsection{Proximate analysis}

Moisture, fat content and ashes of the fish muscle were determined following AOAC (ASSOCIATION..., 2000) in triplicate. Crude protein contents were measured in quadruplicate by a LECO FP-2000 Nitrogen Determinator (Leco Corporation, St Joseph, MI, USA).

\subsection{Viscosity measurement}

Apparent viscosity of muscle homogenate was measured according to Borderías, Jiménez-Colmenero and Tejada (1985) as an indirect means of determining the protein quality of fish muscle. Measurements were performed at $12 \mathrm{rpm}$ with a RV4 spindle, using a Brookfield model DV-III rheometer (Stoughton, MA) and rheocalc V 1.2 software system. Measurements were performed in triplicate and results were expressed in centipoises (cP).

\subsection{Mechanical properties}

Puncture tests (KIM; PARK; YOON, 2004) were performed on samples tempered at room temperature $\left(20-22^{\circ} \mathrm{C}\right)$. Sample dimensions were depth $16 \mathrm{~mm}$ and diameter $96 \mathrm{~mm}$. Each sample was penetrated four times up to breaking point using a $5 \mathrm{~mm}$ diameter cylindrical stainless steel plunger attached to a $50 \mathrm{~N}$ cell connected to the crosshead on a TA-XT2 Texture Analyzer (Texture Technologies Corp., Scarsdale, NY, USA). Force-deformation curves were obtained at $0.2 \mathrm{~mm} / \mathrm{second}$ crosshead speed. The penetration force (PF) is defined as the force $(N)$ required to reach breaking point and the breaking deformation (BD) as the deformation $(\mathrm{mm})$ at which the PF is reached. Work of penetration (WP) is defined as $\mathrm{PF} \times \mathrm{BD}$ $(\mathrm{N} \times \mathrm{mm})$. Determinations were performed in quadruplicate.
Texture Profile Analysis was performed using a TA-XT2 Texture Analyzer as described by Bourne (2002). Seven probes (diameter $=19 \mathrm{~mm}$; height $=12 \mathrm{~mm})$ of raw samples were axially compressed to $40 \%$ of their original height without reaching breaking point. Force-time deformation curves were derived with a $50 \mathrm{~N}$ load cell applied at a crosshead speed of $0.8 \mathrm{~mm} /$ second. Attributes were calculated as follows: hardness $(\mathrm{Hd})=$ peak force $(\mathrm{N})$ required for the first compression; Cohesiveness $(\mathrm{Ch})=$ ratio of active work done under the second compression curve to that done under the first compression curve (dimensionless); springiness $(\mathrm{Sp})=$ distance $(\mathrm{mm})$ the sample recovers after the first compression; chewiness $(\mathrm{Cw})=\mathrm{Hd} \times \mathrm{Ch} \times \mathrm{Sp}(\mathrm{N} \times \mathrm{mm})$. Measurements were performed at room temperature $\left(20-22^{\circ} \mathrm{C}\right)$.

\subsection{Colour measurement}

Gel colour was determined on a HunterLab Mini Scan MS/S-4000S (Hunter Associated Laboratory Inc., Reston, VA) $\left(\mathrm{D} 65 / 10^{\circ}\right)$ using the CIE Lab values, originally defined by the Commission Internationale de $1^{\prime}$ Eclairage: lightness, $\mathrm{L}^{*}$; redness, $\mathrm{a}^{\star}$ and yellowness, $\mathrm{b}^{\star}$ of samples were evaluated on the restructured raw cores (diameter $=19 \mathrm{~mm}$; height $=12 \mathrm{~mm}$ ) as described by Park (1995). Six determinations were performed for each formulation.

\subsection{Cooking loss}

To determine the cooking loss in order to know the behaviour of a prototype product during conventional cooking. Cooking loss was determined as reported by Sánchez-Alonso, Hají-Maleki and Borderías (2007) with some modifications. The raw samples were placed weighed and vacuum wrapped. The bags containing the samples were heated in a bath at $90{ }^{\circ} \mathrm{C} / 30$ minutes. When samples reached room temperature, the exudade was evacuated and the samples were measured again. Water loss due to cooking was defined as the difference in weight before and after cooking.

\section{Results and discussion}

\subsection{Proximate and functional analysis of fish muscle}

The major constituents of the raw fish were: moisture $80.6 \%$ \pm 0.6 , protein $17.1 \% \pm 0.91$, fat $1.1 \% \pm 0.1$ and ash $1.1 \% \pm 0.3$.

The apparent viscosity determined in muscle homogenate was $7519 \mathrm{cP}$. This correlates well with the functional quality of fish muscle protein (BORDERÍAS; JIMÉNEZ-COLMENERO; TEJADA, 1985; KIM; PARK, 2000). On the basis of these viscosity data, the protein quality of this frozen fish muscle may be considered good (BARROSO; CARECHE; BORDERÍAS, 1998).

\subsection{Effect of different calcium sources}

Table 2 shows the results of the analysis of variance of the three regression models with each calcium source. Note the significant contribution of the different calcium sources to the parameters in each model of restructured fish muscle. The effects of each calcium source will be explained separately 
below, indicating the contribution of the significant variable to each parameter.

\section{Effect of calcium chloride}

Analysis of variance indicated that in the case of regression models for colour measurement, only $L^{*}$ and $b^{*}$ values were significant (Table 2). Increasing the amount of $\mathrm{NaCl}$ produced an inverse linear effect $(\mathrm{p}<0.001)$ on $\mathrm{L}^{*}$, and increasing the amount of sodium chloride produced lower lightness values. Moreover, the amount of calcium chloride induced a positive linear effect $(p<0.001)$, i.e. a greater amount of calcium chloride produced a higher lightness value (Table 3 ). $\mathrm{NaCl}$ produced quadratic effects, so that $\mathrm{L}^{*}$ rose considerably at higher concentrations. In this connection, Montero, Hurtado and Pérez-Mateos (2000) reported that the addition of calcium generally promotes lightness in gels of minced Blue whiting (Micromesistius poutassou Risso) irrespective of the hydrocolloid used; that is consistent with the results shown in Table 3, where there are no interactions between sodium alginate and calcium chloride. Trout (1989) reported that when sodium alginate was used without a calcium source, it increased the decolouration in a restructured meat product, but when added along with a calcium source, it protected against decolouration. Because hake muscle is a white fish, this is not readily apparent, but it is an important point for muscles of other colours like salmon or trout. Similarly, in the case of parameter $b^{*}, \mathrm{NaCl}$ produced a negative linear effect $(\mathrm{p}<0.001)$, and $\mathrm{NaCl}$ and $\mathrm{CC}$, respectively, produced negative and positive quadratic effects. Addition of sodium alginate did not contribute to the colour parameters $(\mathrm{p}>0.05)$ (Table 3$)$.

After performing analysis of variance in the regression models for TPA parameters, only cohesiveness was significant (Table 2), while the models for the other TPA parameters were not significant $(\mathrm{p}>0.05)$. This indicates that no significant contribution was found within the range of ingredients studied. Alginate concentration presented a negative linear effect on

Table 2. Analysis of variance of regresion model from $\mathrm{NaCl}$, Sodium alginate and each Calcium source.

\begin{tabular}{|c|c|c|c|c|c|c|}
\hline \multirow[t]{2}{*}{ Parameter } & \multicolumn{2}{|c|}{ Calcium chloride } & \multicolumn{2}{|c|}{ Calcium caseinate } & \multicolumn{2}{|c|}{ Calcium lactate } \\
\hline & Model $^{\text {a }}$ & $\mathrm{R}^{2 \mathrm{a}}$ & Model $^{\text {a }}$ & $\mathrm{R}^{2 \mathrm{a}}$ & Model $^{\text {a }}$ & $\mathrm{R}^{2 \mathrm{a}}$ \\
\hline \multicolumn{7}{|l|}{ Color measurement } \\
\hline$L^{*}$ & $* * *$ & 0,00 & $* * *$ & 0,00 & NS & 0,19 \\
\hline$a^{*}$ & NS & 0,14 & NS & 0,22 & NS & 0,25 \\
\hline$b^{*}$ & * & 0,01 & * & 0,01 & * & 0,01 \\
\hline \multicolumn{7}{|l|}{ Texture profyle analysis } \\
\hline Hardness & NS & 0,43 & * & 0,02 & NS & 0,42 \\
\hline Springeness & NS & 0,20 & NS & 0,68 & NS & 0,34 \\
\hline Cohesiveness & $* *$ & 0,03 & NS & 0,52 & * & 0,03 \\
\hline Chewiness & NS & 0,25 & NS & 0,07 & NS & 0,28 \\
\hline Cooking loss & $* *$ & 0,00 & * & 0,02 & NS & 0,45 \\
\hline \multicolumn{7}{|l|}{ Puncture test } \\
\hline Breaking force & $* *$ & 0,00 & NS & 0,13 & NS & 0,73 \\
\hline Breaking deformation & NS & 0,19 & NS & 0,26 & NS & 0,23 \\
\hline
\end{tabular}

${ }^{* * *}$ significant at $\mathrm{p}<0,001 ;{ }^{* *}$ significant at $\mathrm{p}<0,01 ;{ }^{*}$ significant at $\mathrm{p}<0,05$; NS: not significant; ${ }^{\mathrm{a}}$ Fitted for degrees of freedom.

Table 3. Regresion models fitted for parameters from Calcium Chloride samples.

\begin{tabular}{|c|c|c|c|c|c|c|c|c|c|c|c|c|c|c|c|}
\hline \multirow[t]{2}{*}{ Term } & \multicolumn{3}{|c|}{$L^{*}$} & \multicolumn{3}{|c|}{$\mathrm{b}^{*}$} & \multicolumn{3}{|c|}{ Cohesiveness } & \multicolumn{3}{|c|}{ Breaking force } & \multicolumn{3}{|c|}{ Cooking loss } \\
\hline & $\mathrm{RC}^{*}$ & $\mathrm{SE}^{*}$ & $\mathrm{SL}^{*}$ & $\mathrm{RC}^{*}$ & $\mathrm{SE}^{*}$ & $\mathrm{SL}^{*}$ & $\mathrm{RC}^{*}$ & $\mathrm{SE}^{*}$ & $\mathrm{SL}^{*}$ & $\mathrm{RC}^{*}$ & $\mathrm{SE}^{*}$ & $\mathrm{SL}^{*}$ & $\mathrm{RC}$ & SE & SL \\
\hline Constant & 60,758 & 0,477 & 0,000 & 6,2302 & 0,1738 & 0 & 0,552 & 0,005 & 0,000 & 1,744 & 0,134 & 0,000 & 5,677 & 1,048 & 0,000 \\
\hline \multicolumn{16}{|l|}{ Linear } \\
\hline SA & $-0,234$ & 0,633 & 0,476 & 0,190 & 0,231 & 0,130 & $-0,010$ & 0,007 & 0,016 & $-0,023$ & 0,178 & 0,000 & $-0,232$ & 1,390 & 0,745 \\
\hline $\mathrm{NaCl}$ & $-1,853$ & 0,633 & 0,000 & $-0,576$ & 0,231 & 0,001 & 0,011 & 0,007 & 0,062 & 0,453 & 0,178 & 0,003 & $-0,670$ & 1,390 & 0,357 \\
\hline $\mathrm{CC}$ & 3,057 & 0,633 & 0,000 & 0,002 & 0,231 & 0,986 & 0,001 & 0,007 & 0,702 & $-0,34$ & 0,178 & 0,799 & 4,491 & 1,390 & 0,000 \\
\hline \multicolumn{16}{|l|}{ Quadratic } \\
\hline $\mathrm{SA}^{2}$ & 0,291 & 0,616 & 0,368 & $-0,039$ & 0,225 & 0,733 & 0,000 & 0,007 & 0,934 & 0,347 & 0,173 & 0,002 & $-1,037$ & 1,354 & 0,157 \\
\hline $\mathrm{NaCl}^{2}$ & 0,802 & 0,616 & 0,026 & 0,406 & 0,225 & 0,005 & $-0,009$ & 0,007 & 0,018 & $-0,131$ & 0,173 & 0,161 & 0,778 & 1,354 & 0,277 \\
\hline $\mathrm{CC}^{2}$ & 0,589 & 0,616 & 0,085 & $-0,297$ & 0,225 & 0,024 & $-0,005$ & 0,007 & 0,146 & $-0,001$ & 0,173 & 0,996 & 2,009 & 1,354 & 0,014 \\
\hline \multicolumn{16}{|l|}{ Interactions } \\
\hline $\mathrm{SA}^{\star} \mathrm{NaCl}$ & 0,335 & 0,827 & 0,437 & $-0,046$ & 0,301 & 0,765 & 0,010 & 0,009 & 0,034 & $-0,197$ & 0,232 & 0,120 & $-2,023$ & 1,817 & 0,050 \\
\hline $\mathrm{NaCl}^{*} \mathrm{CC}$ & 0,265 & 0,827 & 0,536 & 0,016 & 0,301 & 0,916 & $-0,020$ & 0,009 & 0,001 & $-0,31$ & 0,232 & 0,028 & 0,090 & 1,817 & 0,923 \\
\hline $\mathrm{CC}{ }^{\star S A}$ & 0,350 & 0,827 & 0,200 & $-0,279$ & 0,301 & 0,094 & 0,012 & 0,009 & 0,022 & $-0,16$ & 0,232 & 0,199 & 0,090 & 1,817 & 0,923 \\
\hline
\end{tabular}

SA: Sodium Alginate (\%); NaCl: Sodium Chloride (\%); CC: Calcium Chloride (\%); ${ }^{\star}$ RC: Regression coeficient; SE: Standar error; SL: Significant level. 
cohesiveness (Figure 1a); Roopa and Bhattacharya (2008) likewise reached the general conclusion that highly cohesive gels were achieved with low concentrations of alginate and calcium chloride. There are interactions between the different components of the model (Table 3), what makes it quite difficult to determine how each ingredient contributes to cohesiveness.

$\mathrm{NaCl}$ concentration produced a positive linear effect on the penetration force of samples (Table 3 and Figure 1b), meaning that a higher $\mathrm{NaCl}$ concentration enhanced the penetration force. This could be due to the ability of $\mathrm{NaCl}$ to enhance protein gelation owing to a lack of interaction between $\mathrm{NaCl}$ and $\mathrm{SA}$ (Table 3). Increasing sodium alginate concentration reduced the penetration force at low concentrations $(0.05-0.14 \%)$, but increased it at higher concentrations (0.4-0.5\%). In this connection, in a study of various hydrocolloids carried out by Pérez-Mateos and Montero (2000), the authors reported that with the addition of high concentrations of sodium alginate (between 0.5 and $4 \%$ ) and the attendant addition of water to homogenize the moisture, protein is diluted, what interferes with the gelation of the myofibrillar protein. Clarke, Sofos and Schmidt (1988) found similar results in a meat muscle system and reported that when high concentrations of sodium alginate were added, the $\mathrm{pH}$ increased and that this hindered the diffusion of calcium ions through the algin's guluronic acid units, thus hampering progressive gelation.
CC concentration was the only component that affected cooking loss positively in this model $(\mathrm{p}<0.001)$ (Table 3 ), meaning that with increasing concentrations there was increasing drip (Figure 1c). Clarke, Sofos and Schmidt (1988) also reported the same phenomenon. However, Montero, Hurtado and Pérez-Mateos (2000) reported an increase of water holding capacity (WHC) when calcium chloride was added in concentrations higher than the ones used in the present work $(0.5 \%)$. In our model, we detected no significant influence of sodium alginate concentration.

\section{Effect of calcium caseinate}

Table 4 shows the regression model fitted for parameters from Calcium caseinate samples. The variance analysis indicated that in the case of the regression models for colour measurement only parameters $L^{\star}$ and $b^{*}$ were significant (Table 4$)$. The addition of $\mathrm{NaCl}$ produced an inverse linear effect $(\mathrm{p}<0.001)$ on $L^{*}$, as happened above in the study of addition of CC, so that $L^{*}$ decreased when CC increased. On the other hand, increasing the amount of sodium alginate produced a positive linear effect ( $p<0.001)$. It is interesting to note that the contribution of sodium alginate to lightness was different depending on the type of calcium source, probably because the different types of bond that were formed created different textures, in which the light would be reflected in different ways. Montero, Hurtado
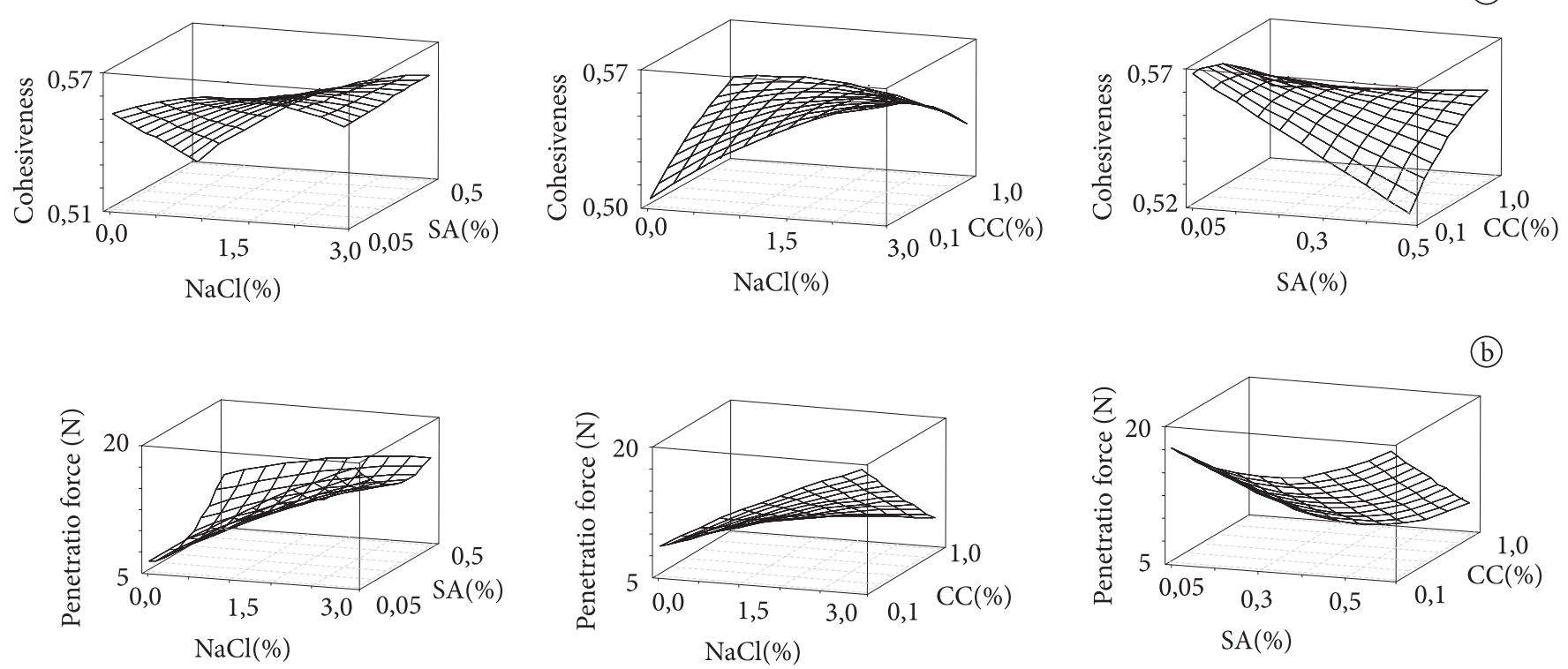

(b)
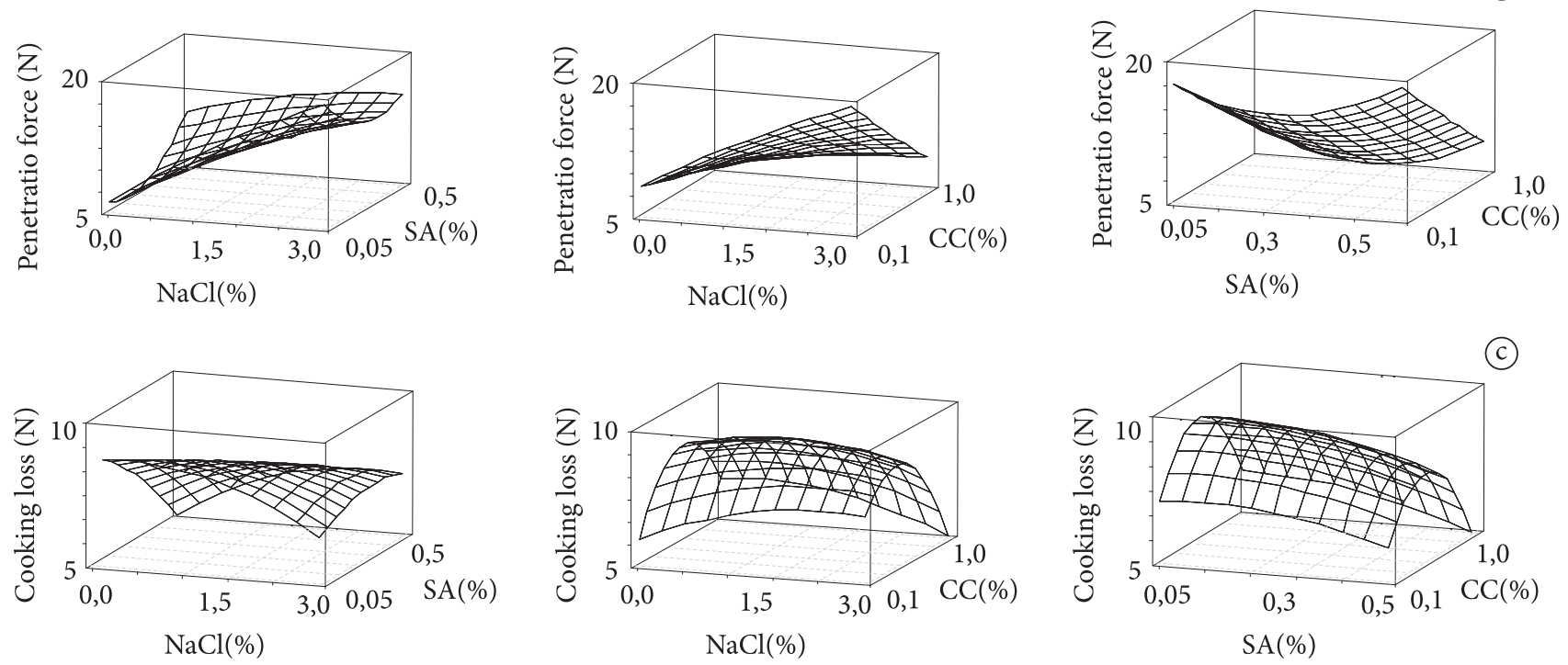

Figure 1. a) Response surface cohesiveness; b) penetration force; and c) cooking loss as a function of $\mathrm{NaCl}(\%), \mathrm{SA}(\%)$ and $\mathrm{CC}(\%)$. 
and Pérez-Mateos (2000) reported that the divalent cation $\left(\mathrm{Ca}^{2+}\right)$ correlates well th the increase in lightness $\left(\mathrm{L}^{*}\right)$. The same was true in the present work in the case of CC; , but in that of CCa no statistical differences weas found. Yellowness was determined by the positive linear contribution of sodium alginate concentration and the negative linear contribution of $\mathrm{NaCl}$ concentration (Table 4).

Analysis of variance indicated that in the case of the regression models for TPA parameters only hardness was significant (Table 2). Increasing the amount of sodium alginate produced an inverse linear effect $(\mathrm{p}<0.001)$ on hardness within the limits of the study (Table 4). On the other hand, when $\mathrm{NaCl}$ and SA were added together, the interaction between them on hardness was positive (Table 4). This agrees with Trot (1989) reporting on restructured beef steaks. However, the increasing of CCaeach variable (Table 4 and Figure 2a).

The contribution to cooking loss (Table 4) was similar to that found in the calcium chloride model (Table 3). Increasing the concentration of CCa increased the cooking loss (Figure 2b). In the present model sodium alginate presented a positive quadratic contribution, meaning that cooking loss increased when large amounts of sodium alginate (0.4-0.5\%) were added. Some authors have reported that the use of calcium alginate in chicken patties can reduce cook loss (TROUT, 1989). Some others have found no differences or increases in cook loss (MEANS; SCHMIDT, 1986; MEANS, 1987). Therefore, as Clarke et al. (1989) proposed, detailed studies of the relationship

Table 4. Regresion models fitted for parameters from Calcium Caseinate samples.

\begin{tabular}{|c|c|c|c|c|c|c|c|c|c|c|c|c|}
\hline \multirow[t]{2}{*}{ Term } & \multicolumn{3}{|c|}{$\mathrm{L}^{*}$} & \multicolumn{3}{|c|}{$b^{*}$} & \multicolumn{3}{|c|}{ Hardness } & \multicolumn{3}{|c|}{ Cooking loss } \\
\hline & $\mathrm{RC}^{*}$ & $\mathrm{SE}^{*}$ & $\mathrm{SL}^{*}$ & $\mathrm{RC}^{*}$ & $\mathrm{SE}^{*}$ & $\mathrm{SL}^{*}$ & $\mathrm{RC}^{*}$ & $\mathrm{SE}^{*}$ & $\mathrm{SL}^{*}$ & $\mathrm{RC}^{*}$ & $\mathrm{SE}^{*}$ & $\mathrm{SL}^{*}$ \\
\hline Constant & 60,227 & 0,311 & 0,000 & 6,745 & 0,0341 & 0,0000 & 7,913 & 0,525 & 0,000 & 1,180 & 0,080 & 0,000 \\
\hline \multicolumn{13}{|l|}{ Linear } \\
\hline SA & 1,306 & 0,412 & 0,000 & 1,089 & 0,453 & 0,001 & $-0,960$ & 0,696 & 0,020 & 0,038 & 0,117 & 0,526 \\
\hline $\mathrm{NaCl}$ & $-1,778$ & 0,412 & 0,000 & $-0,689$ & 0,453 & 0,012 & 0,542 & 0,696 & 0,151 & 0,014 & 0,117 & 0,861 \\
\hline $\mathrm{CCa}$ & 0,084 & 0,412 & 0,694 & 0,327 & 0,453 & 0,180 & 1,199 & 0,696 & 0,006 & 0,248 & 0,117 & 0,002 \\
\hline \multicolumn{13}{|l|}{ Quadratic } \\
\hline $\mathrm{SA}^{2}$ & 0,670 & 0,401 & 0,008 & $-0,070$ & 0,441 & 0,756 & 0,576 & 0,678 & 0,120 & 0,139 & 0,114 & 0,035 \\
\hline $\mathrm{NaCl}^{2}$ & 0,454 & 0,401 & 0,043 & 0,242 & 0,441 & 0,297 & $-0,195$ & 0,678 & 0,578 & 0,070 & 0,114 & 0,249 \\
\hline $\mathrm{CCa}^{2}$ & 0,129 & 0,401 & 0,536 & 0,059 & 0,441 & 0,796 & 0,489 & 0,678 & 0,179 & 0,015 & 0,114 & 0,800 \\
\hline \multicolumn{13}{|l|}{ Interactions } \\
\hline $\mathrm{SA}^{\star} \mathrm{NaCl}$ & 1,306 & 0,539 & 0,001 & 0,686 & 0,592 & 0,057 & 1,409 & 0,909 & 0,011 & 0,199 & 0,153 & 0,026 \\
\hline $\mathrm{NaCl}^{*} \mathrm{CCa}$ & 0,761 & 0,539 & 0,018 & 0,111 & 0,592 & 0,714 & 0,113 & 0,909 & 0,808 & 0,079 & 0,153 & 0,326 \\
\hline $\mathrm{CCa}^{*} \mathrm{SA}$ & $-0,486$ & 0,539 & 0,101 & 0,296 & 0,592 & 0,340 & $-0,008$ & 0,909 & 0,986 & 0,139 & 0,153 & 0,099 \\
\hline
\end{tabular}

SA: Sodium Alginate (\%); NaCl: Sodium Chloride (\%); CCa: Calcium Caseinate (\%); ${ }^{\star}$ RC: Regression coeficient; SE: Standar error; SL: Significant level.

(a)
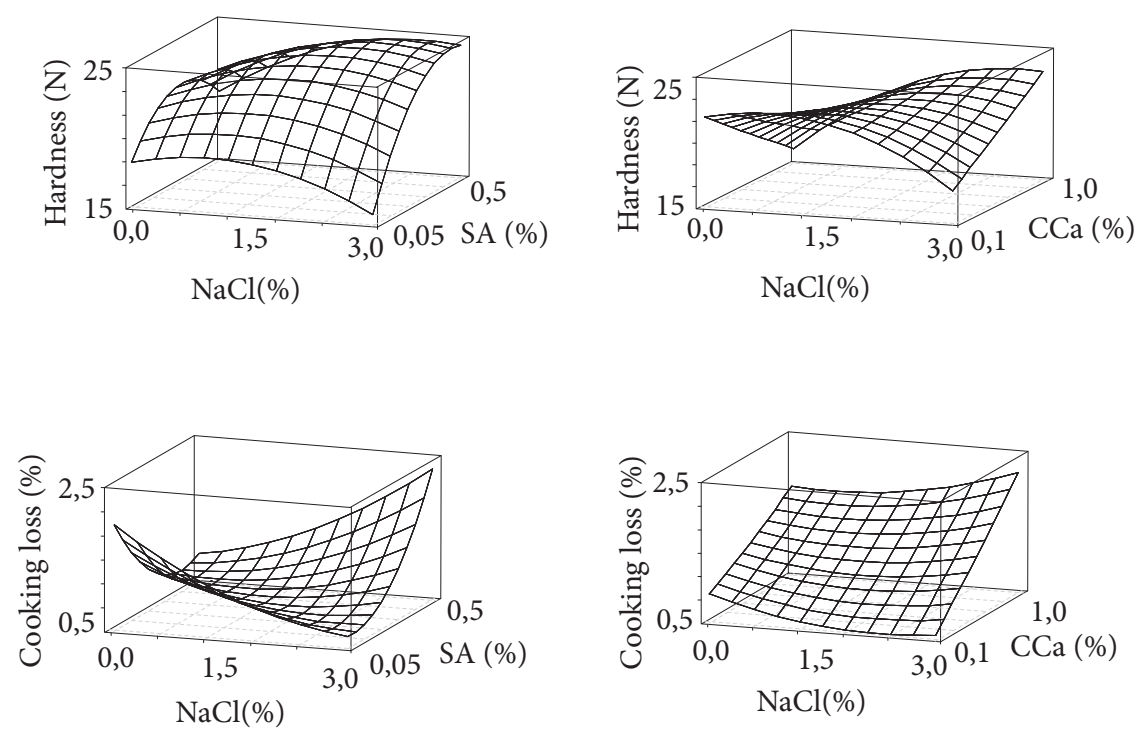

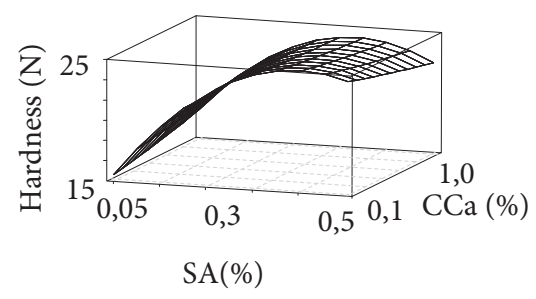

(b)

Figure 2. a) Response surface for hardness; and b) cooking loss as a function of $\mathrm{NaCl}(\%), \mathrm{SA}(\%)$ and CCa (\%). 
Table 5. Regresion models fitted for parameters from Calcium Lactate samples.

\begin{tabular}{|c|c|c|c|c|c|c|}
\hline \multirow[t]{2}{*}{ Term } & \multicolumn{3}{|c|}{$\mathrm{b}^{*}$} & \multicolumn{3}{|c|}{ Cohesiveness } \\
\hline & $\mathrm{RC}^{*}$ & $\mathrm{SE}^{*}$ & $\mathrm{SL}^{*}$ & $\mathrm{RC}^{*}$ & $\mathrm{SE}^{*}$ & $\mathrm{SL}^{*}$ \\
\hline Constant & 3,013 & 0,332 & 0,0000 & 0,555 & 0,007 & 0,0000 \\
\hline \multicolumn{7}{|l|}{ Linear } \\
\hline SA & 0,404 & 0,440 & 0,0957 & 0,003 & 0,010 & 0,6037 \\
\hline $\mathrm{NaCl}$ & $-1,141$ & 0,440 & 0,0004 & 0,022 & 0,010 & 0,0011 \\
\hline CLa & 0,247 & 0,440 & 0,2883 & $-0,001$ & 0,010 & 0,8838 \\
\hline \multicolumn{7}{|l|}{ Quadratic } \\
\hline $\mathrm{SA}^{2}$ & $-0,157$ & 0,429 & 0,4790 & 0,003 & 0,009 & 0,5990 \\
\hline $\mathrm{NaCl}^{2}$ & 0,276 & 0,429 & 0,2273 & $-0,014$ & 0,009 & 0,0123 \\
\hline $\mathrm{CLa}^{2}$ & 0,263 & 0,429 & 0,2473 & 0,005 & 0,009 & 0,2904 \\
\hline \multicolumn{7}{|l|}{ Interactions } \\
\hline $\mathrm{SA}^{\star} \mathrm{NaCl}$ & 0,379 & 0,575 & 0,2173 & 0,004 & 0,012 & 0,9530 \\
\hline
\end{tabular}

SA: Sodium Alginate (\%); NaCl: Sodium Chloride (\%); CLa: Calcium Lactate (\%); ${ }^{\star}$ RC: Regression coeficient; SE: Standar error; SL: Significant level.
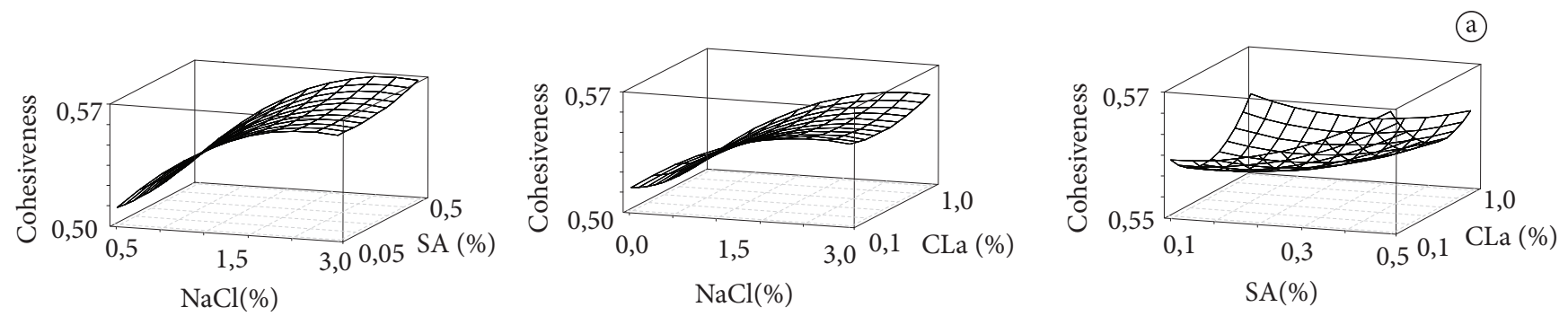

Figure 3. Response surface for cohesiveness as a function of $\mathrm{NaCl}(\%), \mathrm{SA}(\%)$ and CLa (\%).

between the algin/calcium gel matrix and the myofibrillar proteins in structured products may help to understand why cook yield is enhanced in some products but not in others.

\section{Effect of calcium lactate}

According to the analysis of variance for the regression model shown in Table 2, only $\mathrm{b}^{*}$ and cohesiveness were significant. As in all the other models, when using calcium lactate, $\mathrm{NaCl}$ presented a negative linear effect $(\mathrm{p}<0.001)$ on $\mathrm{b}^{*}$, meaning that yellowness increased when its concentration decreased (Table 5). However, negative interactions were detected between $\mathrm{NaCl}$ and $\mathrm{CLa}$, indicating that the effects of each of them were influenced by the effects of the others. The concentration of calcium lactate was not significant $(p>0.05)$ with respect to colour.

Cohesiveness was also significant in this model, as in the $\mathrm{CC}$ model, but in this case only the contribution of $\mathrm{NaCl}$ was statistically significant, presenting a positive linear contribution but a negative quadratic contribution, so that, cohesiveness decreased at high concentrations of $\mathrm{NaCl}$ (2.4-3\%) (Figure 3). Neither sodium alginate nor calcium lactate presented any contribution to cohesiveness (Table 5) in the present work, although the use of CLa with alginate in meat myosystems has been reported to increase binding force and reduce cooking loss (RAHARJO et al., 1994, 1995; ENSOR, 1989).

\section{Conclusions}

The results of the present study show that within the experimental range of each variable studied; addition of sodium alginate and the three different calcium sources produced acceptable restructured fish muscle. The choice of one of the three calcium sources studied depend on what properties are desired.

CC added to sodium alginate/fish muscle systems modifies the mechanical properties of the restructurate more than any of the other calcium sources studied. Increasing concentrations of CC increased lightness and cooking loss. CC by itself did not affect mechanical properties but it influence them through interactions with $\mathrm{NaCl}$.

Addition of CCa increased hardness and cooking loss, and also interacted, to some extent, with $\mathrm{NaCl}$, thus influencing the latter's effect on the lightness.

The addition of CLa did not contribute to any parameter, but it interact with $\mathrm{NaCl}$ to influence the effect on yellowness. 
The effect produced by the concentration of sodium alginate was dependent on the calcium source. When added along with CC at low concentrations $(<0.14 \%)$, it weakened mechanical properties; while at higher concentrations $(>0.4 \%)$ increased the force of penetration. When added along with $\mathrm{CCa}$, it increased $\mathrm{L}^{*}$ and $\mathrm{b}^{*}$ and reduced hardness. Besides, when added with CLa, no effect was detected. Cooking loss was not affected by the addition of sodium alginate in any of the experimental systems.

\section{Acknowledgements}

This research was supported by the "Consejo Superior de Investigaciones Científicas" in the form of a Predoctoral Scholarship under program I3P-2004.

\section{References}

ASSOCIATION OF OFFICIAL ANALYTICAL CHEMISTRY - AOAC. International Official methods of analysis. $17^{\text {th }}$ ed. Maryland: USA, 2000.

BARROSO, M.; CARECHE, M.; BORDERÍAS, A. J. Quality control of frozen fish using rheological techniques. Trends in Food Science \& Technology, v. 9, n. 6, p. 223-229, 1998.

BORDERÍAS, A. J.; JIMÉNEZ-COLMENERO, F.; TEJADA, M. Parameters Affecting Viscosity as a Quality-Control for Frozen Fish. Marine Fisheries Review, v 47, n 4, p. 43-45, 1985.

BOURNE, M. C. Food Texture and Viscosity. Concept and Measurement. $2^{\text {th }}$ ed. Chicago: Inst Food Technologists, 2002. p. 107-187.

CLARKE, A. D.; SOFOS, J. N.; SCHMIDT G. R. Effect of Algin Calcium, $\mathrm{Ph}$ and Muscle Proteins on Gelation and Microstructure of Gels and Structured Beef. Lebensmittel-Wissenschaft und-Technologie, v. 21, n. 1, p. $46-53,1988$.

COCHRAN, W. G.; COX, G. M. Experimental Desings. $2^{\text {th }}$ ed. New York: Wiley International, 1957.

ENSOR, D. Quality characteristics of restructured turkey meat with variable alginate calcium-lactate ratios. Journal of Food Science, v. 54, n. 3, p. 558-565, 1989.

JENA, R.; BHATTACHARYA, S. Viscoelastic cahracyerization of rice gel. Journal of Texture Studies, v. 34, p. 349-360, 2003.

KIM, B. Y.; PARK, L. J.; YOON, W. Rheology and texture properties of surimi gels. In: PARK, J. W. (Ed.) Surimi and surimi seafood. Boca Raton: CRC Press, 2004.

MEANS, W. J. Binding, sensory and storage properties of algin calcium structured beef steaks. Journal of Food Science, v. 52, n. 2, p. 252-257, 1987.

MEANS, W. J.; SCHMIDT, G. R. Algin Calcium Gel as a Raw and Cooked Binder in Structured Beef Steaks. Journal of Food Science, v. 51, n. 1 , p. $60-65,1986$.
MONTERO, P.; HURTADO, J. L.; PÉREZ-MATEOS, M. Microstructural behaviour and gelling characteristics of myosystem protein gels interacting with hydrocolloids. Food Hydrocolloids, v. 14, n. 5, p. 455-461, 2000.

MORENO, H. M.; CARBALLO, J.; BORDERÍAS, A. J. Influence of Alginate and Microbial Transglutaminase as binding ingredients on restructured fish muscle processed at low temperature. Journal of the Science of Food and Agriculture, v. 88, p. 1529-1536, 2008.

MORRIS, E. R. Competitive-inhibition of interchain interactions in polysaccharide systems. Journal of molecular biology, v. 138, n. 2, p. 363-372, 1980.

PARK, J. W. Surimi Gel Colors as Affected by Moisture-Content and Physical Conditions. Journal of Food Science, v. 60, n. 1, p. 15-18, 1995.

PÉREZ-MATEOS, M.; MONTERO, P. Contribution of hydrocolloids to gelling properties of blue whiting muscle. European Food Research Technology, v. 210 , p. 383-390, 2000.

RAHARJO, S. et al. Quality Characteristics of Restructured Beef Steaks Manufactured by various Techniques. Journal of Food Science, v. 60, n.1, p. 68-71, 1995

RAHARJO, S. et al. Restructuring Veal Steaks with Salt. Journal of Food Science, v. 59, n. 3, p. 471-473, 1994.

ROLAND, L. M. et al. Physical and Sensory Properties of Chicken Patties made with Varying Proportions of White and Dark Spent Fowl Muscle. Journal of Food Science, v. 46, n. 3, p. 834-837, 1981.

ROOPA, B. S.; BHATTACHARYA, S. Alginate gels: I. Characterization of textural attributes. Journal of Food Engineering, v. 85, n. 1, p. 123-131, 2008.

SÁNCHEZ-ALONSO, I.; HAJÍ-MALEKI, R.; BORDERÍAS, A. J. Wheat fiber as a functional ingredient in restructurred fish product. Food Chemistry, v. 100, n. 3, p. 1037-1043, 2007.

SHAND, P.J.; SOFOS, J.N.; SCHMIDT, G.R. Properties of Algin Calcium and Salt Phosphate Structured Beef Rolls with Added Gums. Journal of Food Science, v. 58, n. 6, p. 1224-1230, 1993.

STOKKE, B.T. et al. Small-angle scattering and rheological characterisation of alginate gel. Macromolecules, v. 33, n. 1, p. 1853-1863, 2000.

SUKLIM, K. et al. Effect of cold-set binders: Alginates and microbial transglutaminase on the physical properties of restructured scallops. Journal of Texture Studies, v. 35, n. 6, p. 634-642, 2004.

TOLSTOGUZOV, V. B. Functional properties of protein-polysaccharide mixture. In: MICHELL, J.R.; LEDWARD, D. A. Functional properties of food macromolecules. Elsevier Applied Science Publishers Ltd., 1986. p. 85-415.

TROUT, R. G. The effect of Calcium carbonate and sodium alginate on the color and bind strength of restructured beef steaks. Meat Science, v. 25, p. 163-175, 1989.

URDANGARIN, M. et al. Improved solubility and stability of carp myosin by conjugation with alginate oligosaccharide. Fisheries Science, v. 70, p. 896-902, 2004. 